\title{
Composition and basic techniques in pharmacology laboratory: example of in-vitro study of cytotoxic drug candidates
}

\begin{abstract}
The minimum biosafety level of pharmacology laboratory for in-vitro study of cytotoxic drug candidates must be level 2 . To ensure good quality results, the pharmacology laboratory must be equipped of specified material, and researchers must have good laboratory techniques. Globally, we can divide the material for in-vitro studies of drug candidates on cancer cell lines into two parts: the material outside of the culture room and the material inside the culture room. We resume the basic techniques for in-vitro studies of candidates and cytotoxic drugs on cancer cell lines into different steps. First is the preparation step (prepare phosphate-buffered saline; prepare the incubator solution; clean the culture room; prepare the complete culture medium); second is thawing cells; third, check that the cells attached to the bottom of the petri dish or culture flask; fourth, subculture; fifth, cell count; sixth, cryopreservation; seventh, Proliferation and toxicity assays.
\end{abstract}

Volume 9 Issue I - 202 I

\author{
Alexis Zoa ${ }^{1,2}$ \\ 'Pharmacology Department, School of Pharmacy, Gannan \\ Medical University, China \\ ${ }^{2}$ Faculty of Medicine and Biomedical Sciences, The University of \\ Yaoundé I, Cameroon
}

\begin{abstract}
Correspondence: Alexis Zoa, Pharmacology Department of Gannan Medical University, Jiangxi 341000, China,
\end{abstract} Tel 13182715002, Email1918093836@qq.com

Received: November 29, 2020 | Published: January 20, 2021

Keywords: biosafety, pharmacology lab, in-vitro, cells

\begin{abstract}
Abbreviations: OD, optical density (nm); FBS, fetal bovine serum; PBS, phosphate-buffered saline; SD, standard deviation; CCK8, cell counting kit 8; DMSO, dimethyl sulfoxide; ATCC, American type culture collection; EDTA, ethylenediaminetetraacetic
\end{abstract}

\section{Introduction}

Pharmacology can be defined as the study of the actions, uses, mechanisms, and adverse effects of drugs. ${ }^{1}$ A drug is any natural or synthetic substance that alters the physiological state of a living organism. So, pharmacology is an experimental science. Oswald Schmiedeberg, 1838-1921, is considered as the father of modern pharmacology. ${ }^{2}$ In 1869 , Schmiedeberg showed that muscarine evoked the same effect on the heart as electrical stimulation of the vagus nerve. In 1878, he published a classic text, Outline of Pharmacology. Schmiedeberg trained most of the men who became professors at other German universities and in several foreign countries. ${ }^{3}$ Today, there is a pharmacology department in every college of medicine or pharmacy. Experimental pharmacology is done in-vitro and in-vivo. In vivo studies are done in animals, and intact animals are essential for the acute, subacute, and chronic toxicity tests that a new drug substance must undergo, and for important special tests such as teratology and carcinogenicity. Extensive studies of organ toxicity often led researchers to sacrifice animals. Animal welfare organizations oppose animal sacrifices, and in-vitro studies are increasingly prioritized in pharmacological research. The lack of public information on the composition of a pharmacology laboratory for in-vitro studies in the world in general and particularly in Africa has led us to put together this article which is intended to be original and whose main objective is to provide to the heads of pharmacology departments of
African universities in general and sub-Saharan Africa in particular, public information on the equipment of a pharmacology laboratory in order to better equip them, allowing us to carry out pharmacological research on medicinal plants because we believe that Africa has great biodiversity which deserves to be exploited. The information included in this article comes from our personal experience in a pharmacology laboratory in China. We will therefore talk about the equipment of a pharmacology laboratory as well as the basic techniques common to in-vitro studies of cytotoxic drug candidates.

\section{The biohazard safety levels of experimental} lab

There are four categories of biosafety ranging from low to high risk (Table 1). Bio-hazard materials include human pathogens (bacteria, fungi, viruses, parasites, prions); all human blood products, tissues, and body fluids; cultured cells, toxins, and infected tissues. ${ }^{4}$

\section{Material necessary for in vitro studies}

This section deals with the material commonly used in a pharmacology laboratory for in vitro tests, the most common brands (without advertising), and their role. A culture room can be defined as the room keeping or incubating the culture undercontrolled temperature, light, and humidity. The culture room is also fitted with double doors in order to make it dust free and to maintain a constant room temperature. ${ }^{5}$ One should enter the culture room keeping the shoes outside the door. To maintain the temperature around $25 \pm 2^{\circ} \mathrm{C}$ insides the culture room, air coolers are used. The following table (Table 2) present material in two sections, material outside of the culture room and material inside the culture room. 
Table I Categories of biosafety and risk levels

\begin{tabular}{|c|c|c|c|}
\hline Safety level & Risk & Description & Safety requirements \\
\hline \multirow{3}{*}{$\begin{array}{l}\text { Biosafety } \\
\text { Level I }\end{array}$} & \multirow[b]{2}{*}{ Low } & Laboratories appropriate for training and teaching. & \multirow[b]{2}{*}{ Sink for hand washing } \\
\hline & & $\begin{array}{l}\text { Performed with defined and characterized strains of viable micro- } \\
\text { organisms not known to cause any disease in healthy adult humans. }\end{array}$ & \\
\hline & \multirow[b]{2}{*}{ Moderate } & Laboratories appropriate for diagnostics and teaching. & $\begin{array}{l}\text { Primary barriers: Face protection, } \\
\text { gowns, }\end{array}$ \\
\hline \multirow[t]{2}{*}{$\begin{array}{l}\text { Biosafety } \\
\text { Level } 2\end{array}$} & & $\begin{array}{l}\text { Performed with agents that are associated with human diseases (micro- } \\
\text { organisms like Hepatitis B, HIV, most bacteria) as well as human body } \\
\text { fluids, tissues, and primary human cell lines. }\end{array}$ & $\begin{array}{l}\text { Secondary barriers: Sinks for hand } \\
\text { washing, waste decontamination } \\
\text { facilities }\end{array}$ \\
\hline & \multirow{3}{*}{$\begin{array}{l}\text { Moderate- } \\
\text { High }\end{array}$} & $\begin{array}{l}\text { Laboratories appropriate for diagnostics, teaching, research, or } \\
\text { production facilities. }\end{array}$ & $\begin{array}{l}\text { Primary barriers: Aerosol-tight } \\
\text { chamber for work. }\end{array}$ \\
\hline \multirow{2}{*}{$\begin{array}{l}\text { Biosafety } \\
\text { Level } 3\end{array}$} & & & \\
\hline & & $\begin{array}{l}\text { Performed with exotic agents with a potential of respiratory } \\
\text { transmission which may cause serious and potentially lethal infections } \\
\text { (Mycobacterium tuberculosis) }\end{array}$ & $\begin{array}{l}\text { Secondary barriers: Controlled access } \\
\text { to the laboratory }\end{array}$ \\
\hline \multirow[b]{2}{*}{$\begin{array}{l}\text { Biosafety } \\
\text { Level } 4\end{array}$} & \multirow[b]{2}{*}{ High } & Laboratory appropriate for research & $\begin{array}{l}\text { Primary barriers: complete full-body } \\
\text { air-supplied, positive pressure personal } \\
\text { suit (Biosafety Class III cabinets) }\end{array}$ \\
\hline & & $\begin{array}{l}\text { Performed with dangerous and exotic agents that pose a high individual } \\
\text { risk of life-threatening disease, which is transmitted via the aerosol route } \\
\text { and for which there is no vaccine or therapy available (Marburg virus, } \\
\text { Ebola virus) }\end{array}$ & $\begin{array}{l}\text { Secondary barriers: Complete isolated } \\
\text { zone in a separate building }\end{array}$ \\
\hline
\end{tabular}

Recommended work practices, such as the use of appropriate labware, aseptic culture techniques, maintaining a clean working environment, as well as general hygiene (e.g., hand washing, tying back long hair, not eating, drinking, or smoking in the laboratory), are necessary to ensure safety in the lab

Table 2 Name, brand and purpose of material for pharmacology in vitro studies

\begin{tabular}{|c|c|c|}
\hline Name & Brand & Purpose \\
\hline \multicolumn{3}{|l|}{ Outside of the culture room } \\
\hline Autoclave & $\mathrm{PHCbi尺}$ & $\begin{array}{l}\text { Kill harmful bacteria, viruses, fungi, and spores on items that are } \\
\text { placed inside a pressure vessel }\end{array}$ \\
\hline Etuve & Thermo Scientific $®$ & heating and drying of equipment after autoclave sterilization \\
\hline Absorbance machine & Varioskan Lux® & To measure absorbance \\
\hline Nitrogen Transfer Vessel & Thermo Scientific $®$ & $\begin{array}{l}\text { Allows storage at very low temperature }(-130) \text { and over the long } \\
\text { term (several years) of cell lines. }\end{array}$ \\
\hline $\begin{array}{l}\text { Water bath (with adjustable } \\
\text { temperature) }\end{array}$ & JoanLab® & keep materials warm over a period of time \\
\hline Water purification system & Direct-Q尺 5 UV & Provide pure and ultrapure water \\
\hline Precision scale & Mettler toledo $\AA$ & weigh reagents whose weight varies between $10-4$ and $220 \mathrm{~g}$ \\
\hline Fridge, freezers $\left(4^{\circ} \mathrm{C},-20^{\circ} \mathrm{C},-80^{\circ} \mathrm{C}\right)$ & Midea $\AA$ & store reagents and material \\
\hline $\begin{array}{l}\text { Glassware }(2 \mathrm{~L}, \mathrm{IL}, 500 \mathrm{~mL}, 250 \mathrm{~mL}, 100 \\
\mathrm{mL}, 50 \mathrm{~mL}, 25 \mathrm{~mL})\end{array}$ & Pyrex® & Transport liquids \\
\hline Centrifuge tubes $(50 \mathrm{~mL}, 15 \mathrm{~mL})$ & Corning® CentristarTM & $\begin{array}{l}\text { Centrifugation and short-term storage of liquid that we prepared } \\
\text { for an experiment. }\end{array}$ \\
\hline Pipettes and pipettors & Axygen $®$ and DragonLab $®$ & To aliquot different volumes \\
\hline \multicolumn{2}{|c|}{ White coat, surgical masks, care gloves and skullcap } & Protect researcher \\
\hline \multicolumn{2}{|l|}{ Chemical reagent } & Preparation of solutions \\
\hline
\end{tabular}


Table Continued...

\begin{tabular}{|c|c|c|}
\hline Name & Brand & Purpose \\
\hline \multicolumn{3}{|l|}{ Inside of the culture room } \\
\hline Biosafety cabinet & Thermo Scientific $®$ & Create sterile work surface; \\
\hline Humid $\mathrm{CO}_{2}$ incubator & Thermo Scientific $®$ & Provide a physiological environment for cellular growth \\
\hline Inverted light microscope & Leica ${ }^{\circledR}$ & Assess cell morphology and count cells \\
\hline Computer (screen + central unit) & Dell尺 & project what we see under the microscope on a screen \\
\hline Fridge, freezers $\left(4^{\circ} \mathrm{C},-20^{\circ} \mathrm{C}\right)$ & Midea $®$ & Store cell material, and culture components \\
\hline Centrifuge & TDZ5-WS & Condense cells \\
\hline Pipettes and pipettors & Axygen $\circledast$ and DragonLab $\circledast$ & Aliquot different volumes \\
\hline Cryopreservative vials tubes $(I, 8 \mathrm{~mL})$ & & Cryopreservation of cells \\
\hline $\begin{array}{l}\text { Cell media and supplementary } \\
\text { components }\end{array}$ & ATCC $®$ & Culture cells in desirable components \\
\hline Hemacytometer & & $\begin{array}{l}\text { Count cells, determine growth kinetics and prepare suitable plating } \\
\text { densities }\end{array}$ \\
\hline BioTech Automated Cell Counter & Countstar $®$ & $\begin{array}{l}\text { Count cells, determine growth kinetics and prepare suitable plating } \\
\text { densities }\end{array}$ \\
\hline Cell culture dishes & Corning® & Culture cells in different formats (flasks, Petri dishes, 96-well plates) \\
\hline Containers for waste (biohazardous) & & To correctly dispose of waste \\
\hline UV light & & Maintain aseptic environment \\
\hline Alcool $70^{\circ}$ & & To sprinkle on everything that goes in culture room \\
\hline Alcool $95^{\circ}$ & & keep the cabinet flame alive \\
\hline Biofilm & & cover the tubes before storing them in the refrigerator \\
\hline
\end{tabular}

Recommended laboratory equipment for quality results of in-vitro studies of plants extracts on cancer cell lines

\section{How this work in practice (lab protocol)?}

Suppose we want to test a plant extract known for its anticancer activities on HepG2 hepatic carcinoma cells. The first thing to do is to culture these cancer cells so that we have a large quantity to carry out our tests. We will describe a protocol in seven steps.

Note: Wear a white coat, mask, gloves, and cap before any handling in the laboratory.

First step: Preparation

a. Prepare phosphate-buffered saline (PBS) using the formula for 1L: $\mathrm{NaCl}(8 \mathrm{~g}), \mathrm{KCl}(0.2 \mathrm{~g}), \mathrm{Na}_{2} \mathrm{HPO}_{4}(1.44 \mathrm{~g}), \mathrm{KH}_{2} \mathrm{PO}_{4}(0.24 \mathrm{~g})$. Use a precision balance to weigh all reagents and mix them in a $1 \mathrm{~L}$ vial. gradually add purified water. Place the suspension (reagents + purified water) into an autoclave. Control the $\mathrm{pH}=$ 7.4 ;

Note: Autoclave all material to be used in the culture room. Namely: micropipettes, flasks (filled with $2 / 3$ purified water), stainless steel basin of the incubator..

b. Prepare the incubator solution. Add a few crystals of Cooper II sulfate pentahydrate in purified water $(1 \mathrm{~L})$ and place them in the incubator. Ratio 1/10000.;

c. clean the culture room and all the material to use inside the culture room with $70 \%$ alcohol;

d. Prepare the complete culture medium under the biosafety cabinet in multiple steps. Pass the material to be used through a specific
UV-lit window; Before entering the culture room, make sure that the UV light is turned off at least 30 minutes before because it releases $\mathrm{O}_{3}$ which is toxic to humans. Wear a white coat, mask, skullcap, gloves, and shoes intended only for this room; clean the biosafety cabinet with alcohol cotton swap $70 \%$. Open the flame the flame under the safety cabinet; place all the material and solutions necessary for the preparation of our complete medium under the biosafety cabinet. Namely: incomplete culture medium order from ATCC, FBS and antibiotic; Prepare the complete culture medium using the formula $10 \% \mathrm{FBS}, 1 \%$ penicillin/streptomycin and $89 \%$ incomplete culture medium. For example: if we want to prepare $100 \mathrm{~mL}$ of the complete culture medium of HepG2 cells, we will need to have $89 \mathrm{~mL}$ RPMI-1640, $10 \mathrm{~mL} \mathrm{FBS,} \mathrm{and} 1 \mathrm{~mL}$ penicillin/streptomycin.

Second step: thawing cells.

a. Add purified water into the water bath and set the temperature to $37^{\circ} \mathrm{C}$. Wait for the water bath temperature to stabilize at $37^{\circ} \mathrm{C}$;

b. Remove the cryovial containing the cells from liquid nitrogen $\left(\leq-130^{\circ} \mathrm{C}\right)$ andplace it into the water bath. It takes two $(02)$ minutes for cells to suspend;

c. Once the cells suspend, leave for the culture room (wear the clothes specific to this room);

d. Once in the culture room, spray $70 \%$ alcohol on the cryovial and place it into the biosafety cabinet with the other reagents (PBS, complete culture medium); 
e. Remove the suspension (generally $1 \mathrm{~mL}$ ) of the cryovial and put it in a $15 \mathrm{~mL}$ centrifuge tube. Add $4 \mathrm{~mL}$ of the complete culture medium to neutralize the action of DMSO on the cells;

f. Place the centrifuge tube in a centrifuge and centrifuge at 2000 rpm for 5 minutes;

g. After centrifugation, pour the supernatant into the trash;

h. Add $5 \mathrm{ml}$ of our complete medium solution to the tube and mix;

i. Take the suspension (cells + complete medium) and put it into a Petri dish or culture flask. observe under inverse phase microscope (100x magnification);

j. Mark the following information's: the cell line, the name of the manipulator, the date of the manipulation and place the dish or culture flask into the incubator $\left(37^{\circ} \mathrm{C}, 5 \% \mathrm{CO}_{2}, 95 \%\right.$ air) for 24 hours.

Note: Common procedure after any manipulation in the culture room. Close all the tubes and vials used and cover them with parafilm; Spray alcohol 70 and place the tubes and bottles in the fridge $\left(4^{\circ} \mathrm{C}\right)$; Clean the biosafety cabinet with alcohol 70 and cotton; Extinguish the flame and close the biosafety cabinet; Turn on the biosafety cabinet UV; Take out the trash and anything that can no longer be used through the window intended for this purpose; Leave the cell room and turn off the lights; Record the handling done in a register and store the clothes and shoes used in the intended location; Turn on the $U V$ in the cell room and the small transaction room and leave.

Third step: check that the cells have attached to the bottom of the petri dish or culture flask

a. 24 hours later, under the inverted phase microscope check that the cells attached the bottom of the dish.

b. If so, change the culture medium: Pour the previous medium into the waste container and clean the box three times with PBS. The volume of PBS to use depends on the surface of the box. If we have a $25 \mathrm{~cm}^{2}$ culture flask, 2 to $3 \mathrm{~mL}$ of PBS is sufficient. Repeat operation three times;

c. Add the specific culture medium according to the volume of the petri dish.

d. Observe under the inverted phase microscope (the view is clearer) and place into the incubator. Change the medium every two to three days depending on cell growth.

Fourth step: subculture. If confluence $\geq 80 \%$, under biosafety cabinet:

a. Remove the culture medium from the dish and rinse the dish with PBS as described in the previous step;

b. Add 1 to $2 \mathrm{~mL}$ of EDTA trypsin to detach the cells from the bottom of the dish, Place the dish in the incubator for 4 to 5 minutes.

c. Add the complete culture medium to stop the action of the trypsin and Collect the suspension (cells, trypsin, complete culture medium);

d. Centrifuge at $2000 \mathrm{rpm} / \mathrm{min}$ for 5 minutes.

e. After centrifugation, pour in the supernatant and add the culture medium;

f. mix (aspirate / invert several times); Once the mixture is homogeneous, distribute the volume of the suspension in two Petri dishes; g. Mark the following information's: the cell line, the name of the manipulator, the date of the manipulation, and the subculture number. Observe under a microscope and place into the incubator.

Follow the common procedure after any manipulation in the cell room

Fifth step: cell count

a. Hemocytometer count: remove $20 \mu \mathrm{L}$ from the suspension before centrifugation, spread on a hemocytometer, and watch under an inverted-phase microscope (100 x magnifications). Count cells in 04 quadrants. If the cells are very numerous, dilute the $20 \mu \mathrm{L}$ in $1 \mathrm{~mL}$ of solution or PBS and take a further $20 \mu \mathrm{L}$ to spread on the hemocytometer and count; Knowing that 1 quadrant of the hemocytometer corresponds to a volume of $0.1 \mathrm{~cm}^{3}$, average the cell count in 04 quadrants and multiply by $10^{4}$. Example: if in each quadrant we have counted $12,13,14,15$ cells respectively. The cell count will be the average of these 04 values multiplied by the volume of a quadrant, or $13.5 \times 10^{4}$ cells $/ \mathrm{mL}$.

b. Automatic counting (count star): Take $20 \mu \mathrm{L}$ of the stock solution and spread on a count star slide. Place the slide in the count star and choose the corresponding display. Start the automatic calculation from the device and the cell density is displayed. Repeat to make sure that the machine is properly calibrated.

Sixth step: cryopreservation. The cells to be cryopreserved must be counted beforehand. It is important to make sure that the cells are in the exponential growth phase before cryopreserving them.

a. Prepare the cryopreservation medium: complete medium 95\%, DMSO 5\%;

b. Count the cells and be sure of their density $\left(1 \times 10^{6}\right.$ to $5 \times 10^{6}$ cells / $\mathrm{mL}$ ) in the cryopreservation medium

c. Take $1 \mathrm{~mL}$ of suspension (cells + cryopreservation medium) and place in a cryovial.

d. Mark the following information's on the box: the name of the cell line, the name of the manipulator, the cell density, the date of the manipulation, the subculture number.

e. Leave the cryovial at room temperature for 15 minutes, then put in the fridge $\left(4^{\circ} \mathrm{C}\right)$ for 30 minutes, then in the fridge $\left(-20^{\circ} \mathrm{C}\right)$ for 2 hours, then at $-80^{\circ} \mathrm{C}$ overnight. The next day, place the cryovial in liquid nitrogen $\left(-130^{\circ} \mathrm{C}\right)$.

Seventh step: Proliferation and toxicity assay using CCK-8. The CCK-8 assay recommends a minimum density of 2,000 cells per well for cell viability and 5,000 cells per well for cell toxicity using a 96 well plate. A well must contain $100 \mu \mathrm{L}$ of the solution, i.e. a density of $2 \times 10^{4}$ and $5 \times 10^{4}$ cells $/ \mathrm{mL}$ for the viability and the toxicity tests respectively. Make the calculations so that you have the desired densities. We can only use $6 \mathrm{~mL}$ ( 60 wells of $100 \mu \mathrm{L}$ each) to inoculate our cells because the wells at the ends must be occupied by PBS which will evaporate and wells 2 and 3 by the culture medium (blank). Seed the 96 well-plate according to the recommendations above. Avoid the presence of bubbles. Make sure that the medium is always homogeneous for a good distribution of the number of cells in the wells. Place the plate in the incubator for 24, 48 and 72 hours;

\section{Cell proliferation}

a. Find the ideal number of cells to grow for each type of cell line. To do this, inoculate the wells at different densities $\left(10^{4}\right.$, $8 \times 10^{3}, 6 \times 10^{3}, 5 \times 10^{3}, 4 \times 10^{3}, 2 \times 10^{3}$ ) (figure 1). The objective here 
is to find the ideal incubation time (waiting time) for cells after adding CCK-8. The optical density $(0.8<\mathrm{OD}<1.0 ; \mathrm{SD}<0.15)$ and the corresponding time is considered for future experiments.

b. When the cells have attached to the bottom of the plate and if confluence $\geq 80 \%$, remove the culture medium and add $100 \mu \mathrm{L}$ $(90 \mu \mathrm{L}$ medium and $10 \mu \mathrm{L} \mathrm{CCK}-8)$ to each of the wells; place the plate into the incubator for 0.5 - $4 \mathrm{~h}$;

c. Record the absorbance $(450 \mathrm{~nm})$ using Varioskanlux ${ }^{\circledR}$.

d. Analyze the data obtained and draw the standard curve for cell proliferation (figure 2).

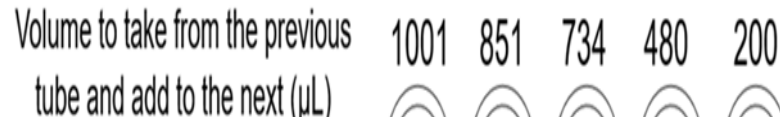
tube and add to the next (pl-

\section{Maximum volume in}
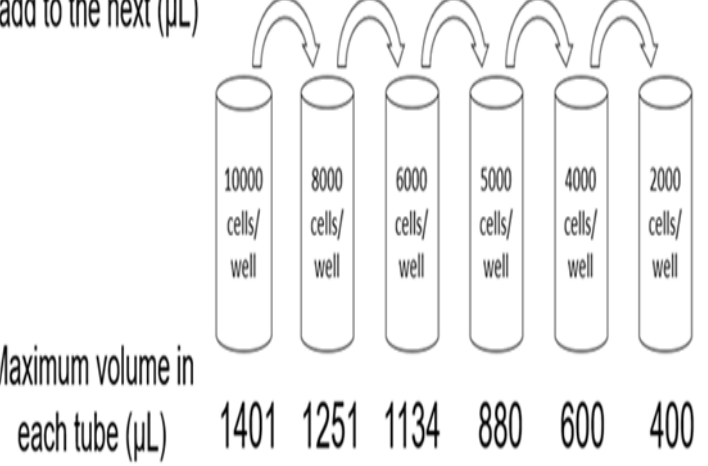

Figure I Protocol to Seed 06 Different Densities of Cells Per Well in Triplicate Using a 96 Well Plate.
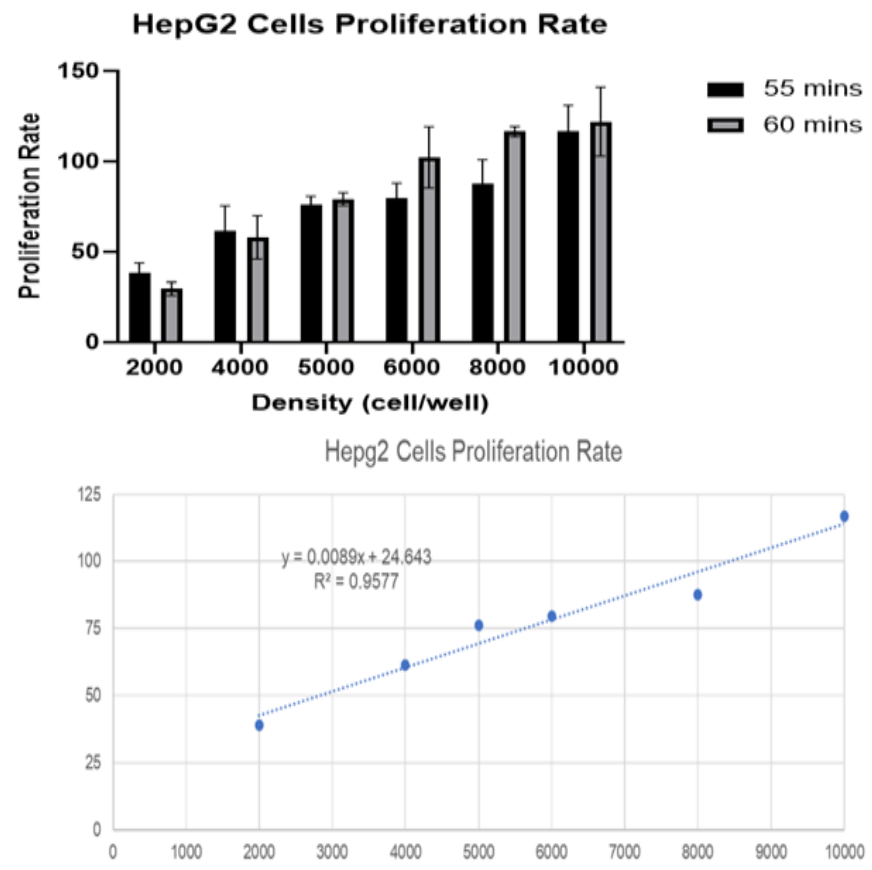

Figure 2 HepG2 cells proliferation rate. We can see that the rate of proliferation double when the cell number double.

Source: ZOA BINDZI, I I/24/2020.

\section{Cell toxicity}

a. if confluence $\geq 80 \%$, remove the culture medium and add the plant extract to be tested at different concentrations and in triplicate in each of the wells where there are cells;

b. Place the plate into the incubator for 24,48 or 72 hours. After each time, remove the medium, and add $100 \mu \mathrm{L}(90 \mu \mathrm{L}$ medium FBS free and $10 \mu \mathrm{L}$ CCK-8) to each well.

c. Incubate the plate for the ideal time (waiting time) identified in the proliferation test, then measure the absorbance. Always note the time of drug and CCK-8 administration to the wells.

d. Record the optical density (OD) and analysis the data obtain.

Note: To add plant extract in 96 well plate, follow the same protocol described in figure 1 .

\section{Conclusion}

The equipment of a pharmacology laboratory for in-vitro studies of cytotoxic drug candidates depends if we are inside or outside the culture room. To ensure good quality results, pharmacology researcher must follow scrupulously Good Laboratory Practices (GLP) for invitro studies. ${ }^{7}$ Any experiment to be reliable must be repeated three times and researcher should avoid contamination by foreign bodies (bacteria, viruses, fungi, etc.), responsible for losses, especially on the financial level, because pharmacological research is quite expensive particularly in developing countries.

\section{Acknowledgments}

We want to thank The Gannan Medical University for the experience acquired in their pharmacology lab.

\section{Competing interests}

The author declares no competing interest.

\section{References}

1. Berger SI, Iyengar. Role of systems pharmacology in understanding drug adverse events. Wiley interdisciplinary reviews Systems biology and medicine 2011;3(2):129-135.

2. Scheindlin S. A brief history of pharmacology. Modern Drug Discovery 2001;4(5):87-88.

3. Candler C, Ihnat M, Huang G. Pharmacology education in undergraduate and graduate medical education in the United States. Clinical Pharmacology \& Therapeutics. 2007;82(2):134-137.

4. Philippeos C, Hughes RD, Dhawan A, e al. Introduction to cell culture. Methods in Molecular Biology. 2012;806:1-13.

5. Segeritz CP, Vallier L. Cell Culture: Growing Cells as Model Systems In Vitro. Basic Science Methods for Clinical Researchers. 2017;151-172.

6. Dojindo. Cell Counting Kit-8. Dojindo Molecular Technologies, Inc; 2021.

7. Idowu B, Di Silvio L. 7-Principles of good laboratory practice (GLP) for in vitro cell culture applications. In: Salih V, editor. Standardization in Cell and Tissue Engineering. Woodhead Publishing; 2013. 127-147 p. 
